\title{
Influence of iron dextran on adjuvant arthritis in the rat
}

\author{
A. G. MOWAT AND R. W. GARNER* \\ Rheumatology Unit, Nuffield Departments of Medicine and Orthopaedic Surgery, University of Oxford, Nuffield \\ Orthopaedic Centre, Oxford
}

Mowat and Hothersall (1968) and Senator and Muirden (1968) have shown considerably higher concentrations of iron, as ferritin, in the synovial tissue of patients with rheumatoid arthritis compared with controls. A similar increase in the quantity of ferritin and in its distribution has been noted in experimental arthritis induced in rabbits with caragheenin, Freund's adjuvant, and tuberculin (Muirden and Peace, 1969). Cullen (1970) has reported the same findings in adjuvant arthritis in rats.

There has been some controversy whether the deposition of iron in the synovial tissue represents beneficial or harmful events (Mowat, 1971). Muirden (1966) and Muirden, Peace, and Rogers (1969) have suggested that the presence of iron in the synovial tissue might be harmful and might lead to the release of lysosomal enzymes, resulting in damage to the joint. There is no evidence for this mechanism. In haemochromatosis there is no clear relationship between the iron storage in the synovial tissue and the associated arthropathy; although there is an increased incidence of chondrocalcinosis, the other articular changes are essentially degenerative (Dymock, Hamilton, Laws, and Williams, 1970). Ball, Chapman, and Muirden (1964) noted only a transient synovitis in rabbit knee joints after the intra-articular injection of very large doses of iron dextran. Others (Brighton, Bigley, and Smolenski, 1970) found evidence of cartilage degeneration in immature rabbits after repeated intramuscular injections of iron dextran. However, there was no evidence of synovitis and the changes did not occur in mature animals.

It has also been suggested that the iron may be beneficial, since Richmond, Roy, Gardner, Alexander, and Duthie (1958) showed that a 5-g. course of saccharated oxide of iron, given intravenously to patients with rheumatoid arthritis, was followed not only by an increase in the haemoglobin concentration but also by a reduction in the erythrocyte sedimentation rate and in the activity of the disease and by an improvement in the functional capacity of the patient.
It has been shown (Mowat, Disney, and Vaughan, 1971) that iron dextran, given by small intraarticular $(200 \mu \mathrm{g}$.) or larger intramuscular $(5 \mathrm{mg}$.) injections, significantly controls an acute synovitis induced in the elbow joint of the guinea-pig by the intra-articular injection of the polyene antibiotic nystatin.

The present investigation was designed to test the effect of iron dextran on adjuvant arthritis in the rat, since this arthritis represents a commonly used experimental model of rheumatoid arthritis and is a better model than the acute, self-limiting synovitis induced by nystatin.

\section{Material and methods}

\section{ANIMALS}

Sixty colony-bred adult Hooded rats (150-250 g.) were maintained on a standard pellet diet and water $a d$ lib.

\section{ADJUVANT INOCULUM}

$25 \mathrm{mg}$. dried heat-killed tubercle bacilli(Central Veterinary Laboratory, Weybridge) were homogenized in $5 \mathrm{ml}$. heavy mineral oil (liquid paraffin B.P.).

\section{QUANTITATION OF ARTHRITIS}

A modification of the method of Currey and Ziff (1968) was utilized. The wrists and ankles were graded 0 to 4 depending upon the degree of thickening, swelling, and redness and each of the smaller joints (metacarpophalangeal, metatarsophalangeal, and interphalangeal) and the tail 0 to 2. The wrist and small joints of the injected paw were scored separately. The total score for the remaining joints and the tail was used as an index of the severity of the polyarthritis (Arthritis Score).

\section{PROCEDURE}

In eighteen animals of each sex arthritis was induced by the intradermal injection of $0.1 \mathrm{ml}$. adjuvant inoculum into the right forepaw on Day 0 . Nine animals in each group received either $1 \mathrm{mg}$. iron as iron dextran (Imferon, Fison's Pharmaceuticals, Loughborough) in $0.1 \mathrm{ml}$. sterile saline or $0.1 \mathrm{ml}$. sterile saline by daily intramuscular injection into the thigh muscles from Day -3 to Day 25 . 
Twelve control animals of each sex received either no treatment (4), iron (4), or saline (4) by intramuscular injection for the same period.

The arthritis score was calculated daily from Day 12 to Day 26 in those animals receiving the adjuvant inoculum All animals were weighed at weekly intervals. All animals were killed by ether anaesthesia on Day 26 and $5 \mathrm{ml}$. blood was obtained by intracardiac puncture for estimation of the plasma iron value (Ramsay, 1957). The usual precautions to avoid iron contamination of the glassware were observed.

\section{Results}

The arthritis score for the iron and saline-treated rats are shown for the sexes separately in the Figure and for the whole series in Table $I$. The combined scores are only significantly different $(P<0.05)$ on Day 19 , when the iron-treated animals had a higher mean score. The iron-treated male rats had higher mean arthritis scores from Day 17 onwards compared with the saline-treated males $(P<0.05)$. The male salinetreated rats had lower arthritis scores than their female counterparts from Day 17 onwards $(P<0.01)$. There were no significant differences between the two female groups or between male and female irontreated animals. There were no differences in the time of appearance or in the degree of the arthritic changes
Table I Arthritis scores in saline-treated and irontreated rats

\begin{tabular}{|c|c|c|}
\hline \multirow{2}{*}{ Day no. } & \multicolumn{2}{|c|}{ Mean arthritis scores $\pm 1 S D$} \\
\hline & Saline-treated & Iron-treated \\
\hline $\begin{array}{l}12 \\
14 \\
17 \\
19 \\
21 \\
24 \\
26\end{array}$ & $\begin{array}{r}3 \cdot 5 \pm 2 \cdot 4 \\
8 \cdot 5 \pm 3 \cdot 4 \\
12 \cdot 0 \pm 4 \cdot 2 \\
13 \cdot 2 \pm 4 \cdot 1 \\
11 \cdot 4 \pm 3 \cdot 4 \\
11 \cdot 8 \pm 3 \cdot 5 \\
10 \cdot 3 \pm 3 \cdot 1\end{array}$ & $\begin{array}{r}3 \cdot 2 \pm 3.4 \\
6.9 \pm 4 \cdot 2 \\
13 \cdot 6 \pm 2 \cdot 7 \\
15 \cdot 5 \pm 3 \cdot 6 \\
12.2 \pm 2.6 \\
11 \cdot 1 \pm 2 \cdot 4 \\
11 \cdot 7 \pm 2 \cdot 0\end{array}$ \\
\hline
\end{tabular}

in the injected paw between any of the groups of animals.

All animals with arthritis showed a similar percentage loss of weight at weekly intervals during the experiment. Similarly, all the control animals showed a similar percentage gain in weight, suggesting that the injection treatment did not affect the animals adversely.

The plasma iron values of the animals at the end of the experiment (Day 26) are shown in Table II (overleaf).

The control group showed no difference between those receiving saline and those untreated. However, the iron-treated controls had significantly higher

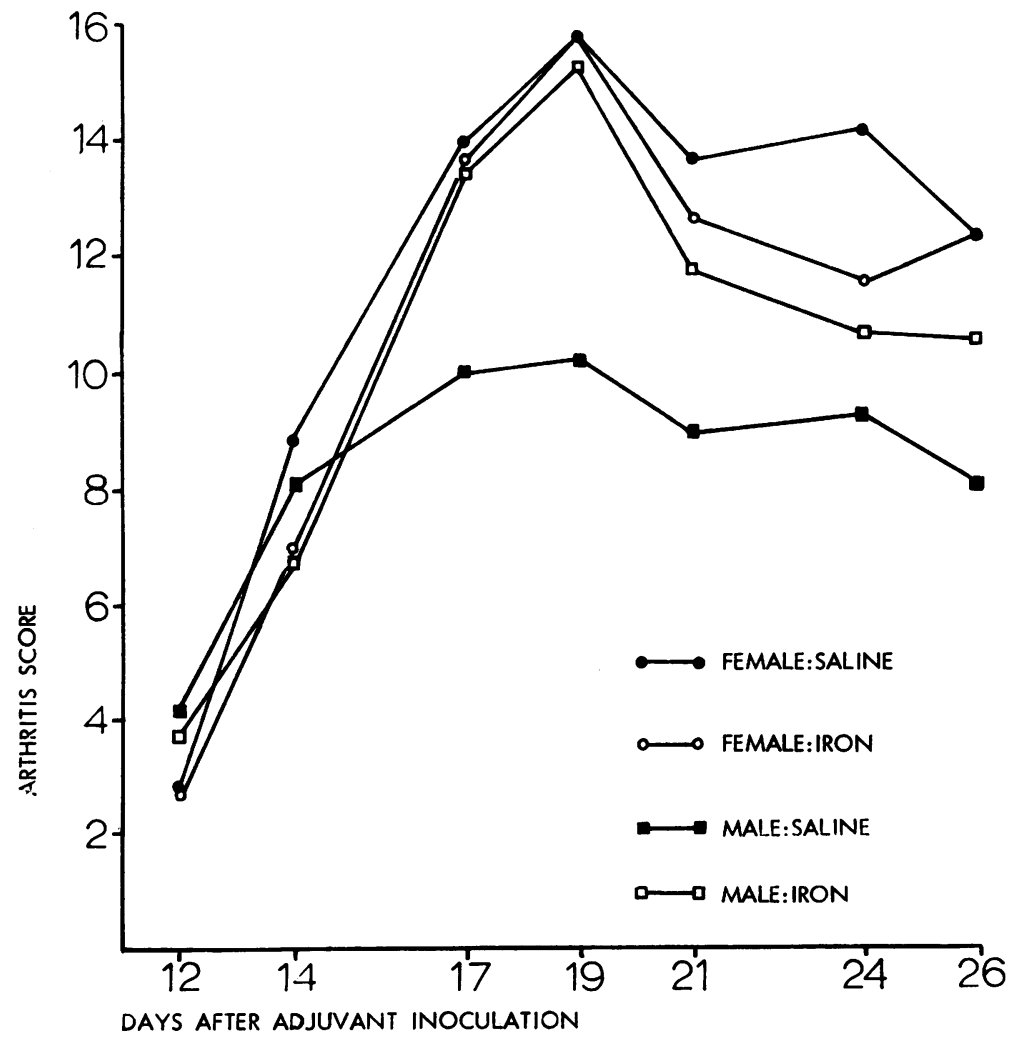

FIGURE Arthritis scores in male and female iron-treated and salinetreated rats 
Table II Mean plasma iron values $(\mu \mathrm{g} . / 100 \mathrm{ml}$ ) on Day 26

\begin{tabular}{|c|c|c|c|c|c|c|}
\hline \multirow{2}{*}{\multicolumn{2}{|c|}{$\frac{\text { Animals }}{\text { Treatment }}$}} & \multicolumn{3}{|l|}{ Control } & \multicolumn{2}{|c|}{ Arthritic } \\
\hline & & Nil & Saline & Iron & Iron & Saline \\
\hline \multirow[t]{2}{*}{ Sex } & $\begin{array}{l}\text { Female } \\
\text { Male }\end{array}$ & $\begin{array}{l}318(4) \\
270(3)\end{array}$ & $\begin{array}{l}284(4) \\
249(4)\end{array}$ & $\begin{array}{l}392(4) \\
339(4)\end{array}$ & $\begin{array}{l}221(9) \\
194(8)\end{array}$ & $\begin{array}{l}146(9) \\
144(9)\end{array}$ \\
\hline & All & 297 & 266 & 365 & 208 & 145 \\
\hline
\end{tabular}

Figures in brackets indicate the number of specimens available for estimation.

plasma iron values $(P<0.05)$. There were no significant sex differences. In the animals with arthritis the irontreated group had significantly higher plasma iron values than those treated with saline $(P<0.01)$. There were no significant sex differences. Plasma iron values of the iron-treated animals with arthritis were significantly lower than the values in all the control groups $(\mathrm{P}<0.01)$.

\section{Discussion}

These results do not support the suggestion of Mowat and others (1971) and Richmond and others (1958) that iron has a beneficial effect on synovial inflammation. Indeed, in our group of male animals, the arthritis was significantly worse in those treated with iron compared with those treated with saline from Day 17 onwards. This increase in the severity of the arthritis was not accompanied by any increased loss of weight nor by any significant change in the plasma iron values compared with the female. Plasma iron values mirror the severity of the arthritis in adjuvant disease in the rat (Lukens, Cartwright, and Wintrobe, 1967; Mikołajew, Kuratowska, Kossakowska, Płachecka, and Kopec, 1969) as they do in adult rheumatoid arthritis (Mowat, Hothersall, and Aitchison, 1969). Such differences in the plasma iron values between saline- and iron-treated arthritic animals and saline and iron-treated controls have been confirmed in this study. The difference in the arthritis score of the male and female saline-treated animals is an interesting observation, since previous workers, using a variety of rat strains, have not been able to demonstrate such sex differences (Swingle, Jaques, and Kvam, 1969).

Mowat and others (1971) suggested, on the basis of the control of an acute, self-limiting synovitis induced in guinea-pigs by the lysosomal enzymereleasing activity of nystatin (Weissmann, Pras, and Rosenberg, 1967) achieved with iron dextran but not with dextran alone, that the iron inhibited the released enzymes. The suggestion of McCarty, Pepe, Solomon, and Cobb (1970) that the increased concentration of iron in the joints of patients with haemochromatosis could be responsible for a reduction in the activity of the enzyme pyrophosphatase leading to the production of calcium pyrophosphate deposition disease (pseudogout syndrome) would support this concept. It might be expected, therefore, that iron therapy could reduce the severity of adjuvant arthritis, since lysosomal enzyme release is the final stage in the inflammatory process.

It is of interest to compare the results in various joint diseases of the effect of gold salts which have been shown to work in a similar manner to that suggested for iron, namely inhibition of lysosomal enzymes after their release (Persellin and Ziff, 1966 Ennis, Granda, and Posner, 1968; Paltenaa, 1968). Gold salts are beneficial in patients with rheumatoid arthritis whether given parenterally (Empire Rheumatism Council, 1961) or intra-articularly (Lewis and Ziff, 1966). Mowat and others (1971) found them to be approximately half as effective as iron on the basis of elemental weight in their guinea-pig system. There have been conflicting reports of their effect in adjuvant arthritis in the rat. Newbould (1963), using small quantities of gold, and Walz, Di Martino, and Misher (1971), using very large quantities of gold, were both able to reduce the severity of the polyarthritis, and Walz and others (1971) showed that the results were dose dependant. However, Jessop and Currey (1965), using a moderate quantity of gold, given as in the other experiments by daily intramuscular injection were unable to alter the course of the polyarthritis.

The dose of iron used in this study was within the range employed therapeutically in patients with rheumatoid arthritis (Duthie, 1967) and in whom a beneficial effect upon the activity of the disease has been reported (Richmond and others, 1958). Furthermore, the dosage level was similar to that of gold used by Jessop and Currey (1965). The programme of daily injections starting 3 days before the injection of the adjuvant inoculum is similar to that employed by other workers, who have shown that drugs used in rheumatoid arthritis are effective in controlling adjuvant disease in the rat (Walz and others, 1971). It might be that a more obvious effect of iron dextran on adjuvant arthritis would be demonstrated by the administration of larger quantities of iron, although those employed in this study were sufficient to produce significant changes in the plasma iron values.

In the light of this work it is impossible to make any suggestions as to the likely effect of iron preparations in patients with rheumatoid arthritis. However, the conflicting reports of the effect of gold salts in adjuvant disease in rats suggests that this disease may not always represent an accurate model of rheumatoid arthritis, and that direct comparisons between the 
effect of treatment in the two diseases are not always justified.

\section{Summary}

Reports of the possible anti-inflammatory activity of iron on synovial inflammation led to an attempt to control the polyarthritis of adjuvant disease in rats by the daily intramuscular injection of iron dextran.

No effect was demonstrated, despite significant elevation of the plasma iron values in the treated animals.

The results are compared with the conflicting results of the effect of gold salts in this disease and it is suggested that adjuvant disease in rats may not always represent an accurate model of rheumatoid arthritis.

A.G.M. gratefully acknowledges a grant from the Arthritis and Rheumatism Council which enabled this study to be undertaken.

\section{References}

Ball, J., Chapman, J. A., AND Muirden, K. D. (1964) J. Cell Biol., 22, 351 (The uptake of iron in rabbit synovial tissue following intra-articular injection of iron dextran)

Brighton, C. T., Bigley, E. C., AND SMOlenski, B. I. (1970) Arthr. and Rheum. 13, 849 (Iron induced arthritis in immature rabbits)

Cullen, J. C. (1970) B.Sc. Thesis, University of Oxford (A study of mesenchymal cells such as the mast cell and the fibroblast in adjuvant arthritis)

CuRrey, H. L. F., AND ZIFF, M. (1968) J. exp. Med., 127, 185 (Suppression of adjuvant disease in the rat by heterologous antilymphocyte globulin)

DUTHIE, J. J. R. (1967) Scot. med. J., 12, 96 (Medical management and prognosis in rheumatoid arthritis)

Dymock, I. W., Hamilton, E. B. D., Laws, J. W., and Williams, R. (1970) Ann. rheum. Dis. 29, 469 (Athropathy of haemochromatosis: Clinical and radiological analysis of 63 patients with iron overload)

EMPIRE RHEUMATISM CouNCIL (1961) Ibid., 20, 315 (Gold therapy in rheumatoid arthritis)

ENNis, R. S., Granda, J. L., AND Posner, A. S. (1968) Arthr. and Rheum., 11, 756 (Effects of gold salts and other drugs on the release and activity of lysosomal hydrolases)

Jessop, J. D., AND CuRREY, H. L. F. (1968) Ann. rheum. Dis., 27, 577 (Influence of gold salts on adjuvant arthritis in the rat)

LEWIS, D. C., AND ZIFF, M. (1966) Arthr. and Rheum., 9, 682 (Intra-articular administration of gold salts)

Lukens, J. N., Cartwright, G. E., AND Wintrobe, M. M. (1967) Proc. Soc. exp. Biol. (N.Y.), 126, 346 (Anaemia of adjuvant-induced inflammation in rats)

McCarty, D. J., PePe, P. F., Solomon, S. D., AND CobB, J. (1970) Arthr. and Rheum., 13, 336 (Inhibition of human erythrocyte pyrophosphatase activity by calcium, cupric, and ferrous ions)

Mikolajew, M., Kuratowska, Z., Kossakowska, M., Pzachecka, M., and Kopec, M. (1969) Ann. rheum. Dis., 28, 172 (Haematological changes in adjuvant disease in the rat. II. Iron metabolism and ${ }^{51} \mathrm{Cr}$ erythrocyte survival)

MowAT, A. G. (1971) 'Anaemia in Rheumatoid Arthritis', in Modern Trends in Rheumatology, 2, ed. A. G. S. Hill, p. 106. Butterworths, London

- Disney, T. F., AND Vaughan, J. H. (1971) Ann. rheum. Dis., 30, 187 (Effect of iron dextran, gold thiosulphate, and hydrocortisone acetate on experimental synovitis in the guinea-pig)

- AND HotHERSALL, T. E. (1968) Ibid., 27, 345 (Nature of anaemia in rheumatoid arthritis. VIII. Iron content of synovial tissue in patients with rheumatoid arthritis and in normal individuals)

,-- , AND ArTCHISON, W. R. C. (1969) Ibid., 28, 303 (Nature of anaemia in rheumatoid arthritis. XI. Changes in iron metabolism induced by the administration of corticotrophin)

MUIRDEN, K. D. (1966) Ibid., 25, 387 (Ferritin in synovial cells in patients with rheumatoid arthritis)

- AND PEACE, G. (1969) Ibid., 28, 392 (Light and electron microscope studies in caragheenin, adjuvant, and tuberculin-induced arthritis)

,-- , AND ROGERS, K. (1969) Ibid., 28, 630 (Clearance of $\mathrm{Fe}^{59}$-labelled erythrocytes from normal and inflamed rabbit knee joints. II. Autoradiographic and histological studies)

Newbould, B. B. (1963) Brit. J. Pharm., 21, 127 (Chemotherapy of arthritis induced in rats by mycobacterial adjuvant)

PaltenaA, S. (1968) Acta rheum. scand., 14, 161 (The inhibition of lysosomal enzymes by gold salts in human synovial fluid cells)

Persellin, R. H., AND Ziff, M. (1966) Arthr. and Rheum., 9, 57 (The effect of gold salt on lysosomal enzymes of the peritoneal macrophage)

Ramsay, W. N. M. (1957) Clin. chim. Acta, 2, 214 (Determination of iron in blood plasma or serum)

Richmond, J., Roy, L. M. H., Gardner, D. L., Alexander, W. R. M., AND Duthie, J. J. R. (1958) Ann. rheum. Dis., 17, 406 (Nature of anaemia in rheumatoid arthritis. IV. Effects of the intravenous administration of saccharated oxide of iron)

SenatoR, G. B., AND MUIRDEN, K. D. (1968) Ibid., 27, 49 (Concentration of iron in synovial membrane, synovial fluid, and serum in rheumatoid arthritis and other joint diseases) 
Swingle, K. F., JaQues, L. W., AND Kvan, D. C. (1969) Proc. Soc. exp. Biol. (N. Y.), 132, 608 (Differences in the severity of adjuvant arthritis in four strains of rats)

Walz, D. T., Di Martino, M. J., AND Misher, A. (1971) Ann. rheum. Dis., 30, 303 (Suppression of adjuvant-induced arthritis in the rat by gold sodium thiomalate)

Weissmann, G., Pras, M., AND Rosenberg, L. (1967) Arthr. and Rheum., 10, 325 (Arthritis induced by filipin in rabbits) 